\title{
Human health effects of a changing global nitrogen cycle
}

\author{
Alan R Townsend ${ }^{1}$, Robert W Howarth ${ }^{2}$, Fakhri A Bazzaz ${ }^{3}$, Mary S Booth ${ }^{4}$, Cory C Cleveland ${ }^{5}$, \\ Sharon K Collinge ${ }^{6}$, Andrew P Dobson ${ }^{7}$, Paul R Epstein ${ }^{8}$, Elisabeth A Holland ${ }^{9}$, Dennis R Keeney ${ }^{10}$, \\ Michael A Mallin ${ }^{11}$, Christine A Rogers ${ }^{12}$, Peter Wayne ${ }^{13}$, and Amir H Wolfe ${ }^{14}$
}

Changes to the global nitrogen cycle affect human health well beyond the associated benefits of increased food production. Many intensively fertilized crops become animal feed, helping to create disparities in world food distribution and leading to unbalanced diets, even in wealthy nations. Excessive air- and water-borne nitrogen are linked to respiratory ailments, cardiac disease, and several cancers. Ecological feedbacks to excess nitrogen can inhibit crop growth, increase allergenic pollen production, and potentially affect the dynamics of several vector-borne diseases, including West Nile virus, malaria, and cholera. These and other examples suggest that our increasing production and use of fixed nitrogen poses a growing public health risk.

Front Ecol Environ 2003; 1(5): 240-246

$\mathrm{H}$ uman activity now fixes more atmospheric $\mathrm{N}_{2}$ into reactive forms (Panel 1) than all terrestrial natural processes combined (Galloway et al. 1995; Vitousek et al. 1997). The resulting environmental effects are widespread and increasingly well-documented (Vitousek et al. 1997), but there are also diverse consequences for human health (Wolfe and Patz 2002). Some of these are well recognized, such as the benefits of increased food production and the risks of air pollution, but the full scope of connections between a changing $\mathrm{N}$ cycle and human health is not yet widely appreciated. As with ecological responses to changing $\mathrm{N}$, the health effects range from well-documented to largely theoretical. Human changes in response to the $\mathrm{N}$ cycle also clearly have both negative and positive implications for health.

We suggest the net public health consequences of a changing $\mathrm{N}$ cycle are largely positive at lower levels, but they eventually peak and then become increasingly negative as our creation and use of fixed $\mathrm{N}$ continues to climb (Figure 1). Since quantitative data on many of the links between a changing $\mathrm{N}$ cycle and human health are still very sparse, we present this model as a conceptual framework; substantial additional data are needed to rigorously evaluate this hypothesis. This conceptual model is similar to the "N saturation" model of ecosystem responses to rising $\mathrm{N}$ inputs (Aber et al. 1989; Ågren and Bosatta 1998), and suggests that the initial rise in health benefits associated with human $\mathrm{N}$ fixation occurs for both agricultural and industrial pathways. For example, in developing countries, low to moderate increases in fertilizer use will

\footnotetext{
${ }^{1}$ Institute of Arctic and Alpine Research and Dept of Ecology and Evolutionary Biology, University of Colorado, Boulder, CO (alan.townsend@colorado.edu); ${ }^{2}$ Department of Ecology and Evolutionary Biology, Cornell University, Ithaca, NY; ${ }^{3}$ The Biological Labs, Harvard University, Cambridge, MA (continued on final page)
}

improve food availability and overall nutrition, with only minor elevated losses of reactive $\mathrm{N}$ to the environment. In addition, although lower levels of fossil fuel combustion still contribute to the greenhouse gas burden, they do not lead to severe air pollution, and moderate development of industrial and transportation systems in poorer, rural nations tends to improve public health (Berry 1992).

However, as both agricultural and industrial activities intensify, $\mathrm{N}$ losses to the environment have a range of both direct and indirect feedbacks to human ailments. Moreover, many crops harvested from intensively fertilized regions become animal feed, leading to a further cascade of $\mathrm{N}$ losses to the environment, the dangers of an unbalanced diet, even in wealthy nations, and disparities in world food distribution. Thus, the health benefits of increasing $\mathrm{N}$ probably saturate, while the negative consequences increase and become more varied.

\section{Fertilizer, food production, and nutrition}

Much of the world's agriculture is limited by N, and its use as a fertilizer has expanded so dramatically that this now represents the single largest alteration of the $\mathrm{N}$

\section{In a nutshell:}

- Human usage of reactive nitrogen affects human health in both positive and negative ways

- The health benefits probably saturate as rates of reactive $\mathrm{N}$ creation and use climb, whereas the negative consequences increase and diversify

- The negative health consequences of increasing $\mathrm{N}$ are both direct (eg air and water pollution) and indirect (eg ecological feedbacks to disease)

- Reductions in both the environmental and health problem associated with a changing nitrogen cycle are possible 
cycle. The rate of change is remarkable: half of all the inorganic $\mathrm{N}$ ever used on the planet was applied in the past 15 years (Howarth et al. 2002). In poor nations with substantial hunger problems, increased $\mathrm{N}$ fertilizer use can considerably reduce malnutrition (Sanchez 2002). Indeed, inorganic fertilizers - an essential component of the green revolution - have led to a tremendous increase in world food production since the 1960s. Consequently, despite large population increases over the same time period, starvation and malnutrition have declined in many regions, particularly Asia (Smil 2000). This clearly represents an enormous health benefit from N. Moreover, beyond the obvious benefits of decreasing hunger and malnutrition, a healthy diet plays a major role in a person's ability to mount an efficient immune response against parasitic and infectious diseases (Beisel 1982; Nesheim 1993). Thus, as shown in Figure 1, increased N fertilizer use in impoverished nations can produce considerable public health benefits.

The worldwide distribution of food is far from optimal, however. Malnutrition and hunger are still widespread in some regions, but these are now caused primarily by inequitable food distribution, rather than inadequate production per se (Smil 2000). In addition, the benefits of improved diets in some developing countries are countered by the rich, often unbalanced diets that are increasingly common in many of the world's wealthier nations (Zimmet et al. 2001).

One reason for suboptimal diets at both ends of the economic spectrum is that much of the world's grain production is used for animal feed or for commercial and industrial uses. In the US, over half of the grain produced is fed to animals, and far more corn is used for commercial sweeteners than for direct human consumption (Howarth et al. 2002). Feed crops such as corn are fertilized at high levels, so increased meat production and consumption has been a significant driver behind rising $\mathrm{N}$ fertilizer use. Per capita meat consumption has doubled in the developing world since 1960, and has also grown exponentially in the US, largely as a result of increased poultry consumption (Howarth et al. 2002).

There are strong arguments that meat proteins may be an important part of human diets (Smil 1997). However, high consumption of meat and some commercial grain products such as corn sweeteners can be linked to a range of health problems that are common in developed countries, including heart disease and diabetes (Hu and Willett 2002; van Dam et al. 2002; Weisburger 2002). In addition, the environmental and health consequences of meat production and consumption vary with the way in which animals are raised. Beef, pork, chicken, and turkey are all increasingly produced in concentrated animal feeding operations (CAFOs), where the animals are fed intensely fertilized grain products (Mallin 2000). CAFOs lead to a cascade of environmental problems that can also have human health implications (Mallin 2000), and some evidence suggests that meat from CAFO-raised animals is less

\section{Panel 1. Reactive nitrogen}

The bulk of the atmosphere is $\mathrm{N}_{2}$ gas, yet this form of nitrogen is not available to most of earth's biota. Thus, the rate at which $\mathrm{N}_{2}$ is "fixed" into biologically available forms is vital in determining the structure and function of terrestrial, freshwater and marine ecosystems (Delwiche 1970; Vitousek and Howarth 1991). Humans are dramatically changing the rate of $\mathrm{N}_{2}$ fixation, largely via fertilizer production, fossil fuel combustion, and widespread cultivation of $\mathrm{N}_{2}$-fixing crop species (Galloway et al. 1995; Vitousek et al. 1997). These activities lead to an increase in multiple forms of $\mathrm{N}$ that are available to the biota, can move readily among terrestrial, aquatic and atmospheric realms, and that can alter the chemistry and/or radiative balance of the atmosphere. Galloway et al. (1995) labeled this diverse pool of $\mathrm{N}$ as "reactive N", and defined the term to include all biologically, radiatively, and/or photochemically active forms of the element. Examples include, but are not limited to: $\mathrm{NO}_{3}{ }_{3}^{-}$and $\mathrm{NH}_{4}{ }^{+}$, the predominant forms of $\mathrm{N}$ taken up by organisms, $\mathrm{NO}_{x}$ and $\mathrm{NH}_{3}$, which are chemically important in the troposphere, and $\mathrm{N}_{2} \mathrm{O}$, which is an important greenhouse gas in the troposphere and can catalyze ozone destruction in the stratosphere. See Galloway et al. (1995),Vitousek et al. (1997) and Galloway and Cowling (2002) for additional details on the forms and consequences of increasing reactive $\mathrm{N}$ in the environment.

healthy than meat from animals raised in more traditional ways (Cordain et al. 2002). The widespread and growing use of CAFOs in meat production would not be possible without relatively cheap and abundant $\mathrm{N}$ fertilizer.

Finally, the environmental consequences of increases in reactive $\mathrm{N}$ can have negative effects on food supply. For example, $\mathrm{N}$-fueled eutrophication of marine coastal waters contributes to harmful algal blooms and fish kills (Burkholder 1998), as well as causing dead zones and reef degradation that can harm shellfish and fisheries (NRC 2000). On land, high levels of tropospheric ozone $\left(\mathrm{O}_{3}\right)$, driven by excess atmospheric $\mathrm{N}$ oxides, may cause billions of dollars in crop damage (Chameides et al. 1994). Modern, $\mathrm{N}$-intensive agriculture can also reduce soil fertility through acidification, promote "weedy" species invasions, and elevate the risk of agricultural pests and diseases (Matson et al. 1997).

\section{Direct health effects of changing $N$}

Human-driven increases in reactive $\mathrm{N}$ in the environment have some clear and direct consequences for human health. By direct, we mean health effects due to the ingestion of $\mathrm{N}$-containing compounds in air or water, or compounds and particulates produced because of excess reactive $\mathrm{N}$ in those reservoirs. Such effects fall into two major classes: air pollution and drinking water nitrate.

\section{Air pollution}

Air pollution is a widely recognized public health issue, 


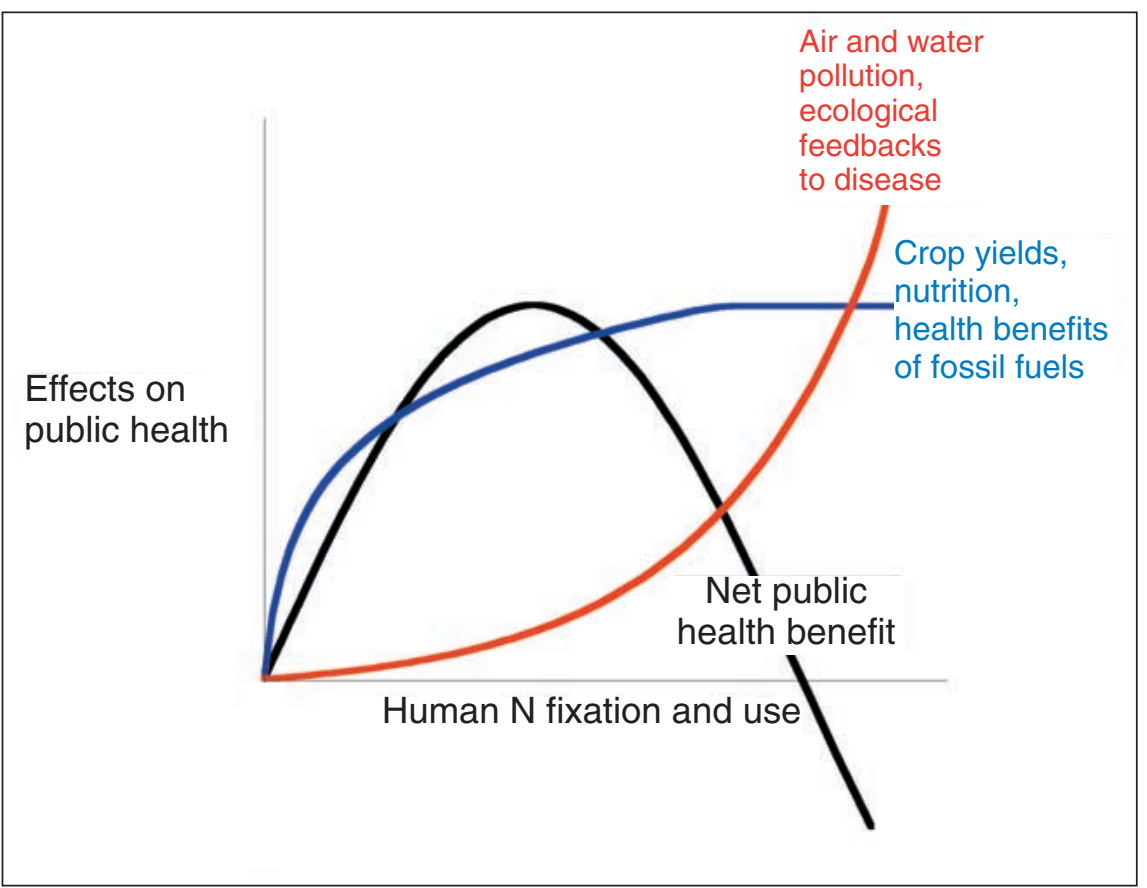

Figure 1. Conceptual model of the overall net public health effects of increasing human fixation and use of atmospheric $\mathrm{N}_{2}$. As human $\mathrm{N}_{2}$ fixation and use rises, the positive effects of $N$ on crop growth, food production, and overall nutrition peak (and potentially begin to decrease). A similar pattern appears in the public health benefits of increasing fossil fuel use associated with better city infrastructure and transportation. In contrast, rising $N$ inputs create exponential increases in losses of $N$ to air and water, deposition to natural ecosystems, and potential feedbacks between rising $N$ availability and the ecological dynamics of environmentally-harbored diseases.

and a changing $\mathrm{N}$ cycle plays an important role in several ways. First, elevated emissions of nitrogen oxides $\left(\mathrm{NO}_{\mathrm{x}}\right)$ from fossil fuel combustion, biomass burning, and fertilizer use all contribute to high atmospheric levels, especially in urban areas. High $\mathrm{NO}_{\mathrm{x}}$ leads to the production of tropospheric $\mathrm{O}_{3}$ (Chameides et al. 1994), and reactive airways disease (RAD), coughs, and asthma can be initiated and exacerbated by $\mathrm{O}_{3}$ exposure. Ozone also induces respiratory tract inflammation, leads to short-term reductions in lung function, and aggravates chronic respiratory disease (von Mutius 2000). Children who exercise in environments high in $\mathrm{O}_{3}$ are $40 \%$ more likely to develop asthma (McConnell et al. 2002), and asthma rates are increasing in many parts of the world, despite advances in treatment (Beasley et al. 1998).

In addition, urban levels of $\mathrm{NO}_{\mathrm{x}}$ can lengthen and worsen common viral infections such as human rhinovirus, significantly elevating the risks to asthmatics and individuals with compromised immune systems (Spannhake et al. 2002). High indoor $\mathrm{NO}_{2}$ levels can also induce a variety of respiratory illnesses, and in the developing world, indoor air pollution may account for nearly 2 million deaths per year (Wolfe and Patz 2002). The relative importance of $\mathrm{N}$-containing species in this disease burden is not well quantified, but could potentially be substantial (Wolfe and Patz 2002).

Second, multiple studies have shown positive correla- tions between fine particulate air pollution and cardiovascular diseases, respiratory diseases, asthma, reduced lung function, and overall mortality (Pope et al. 2002). Not all fine particulates are products of a changing $\mathrm{N}$ cycle, and the relative contribution of reactive atmospheric $\mathrm{N}$ to overall particulate loads varies considerably between population centers (Malm et al. 2000). Nonetheless, reactive $\mathrm{N}$ is clearly an important driver of particulate air pollution worldwide, and can be the dominant one in some regions. For example, ammonium and nitrate containing particulates constitute as much as $65 \%$ of the total atmospheric load in southern California (Malm et al. 2000).

Third, human allergic response to pollen is a pervasive environmental health issue. Millions suffer from hay fever, allergenic rhinitis, and allergenic asthma each year, following exposure and sensitization to pollen (NIH 1993). Pollen counts are rising, probably for many reasons, including climatic change, disturbance-driven changes in species composition, and elevated atmospheric $\mathrm{CO}_{2}$ (Wayne et al. 2002), but increasing $N$ availability can also stimulate greater pollen production (Lau et al. 1995). The effects of $\mathrm{N}$ on pollen are likely to vary with species, but it is noteworthy that $\mathrm{N}$ additions to ragweed, a widespread producer of allergenic pollen, caused dramatic increases in pollen production (Figure 2).

\section{Drinking water nitrate}

The World Heath Organization has adopted a $10 \mathrm{ppm}$ nitrate-N maximum standard for safe drinking water, but worldwide this standard is often exceeded. Groundwater nitrate contamination associated with fertilizer use is common in both developed and developing regions (Oenema et al. 1998; Agrawal et al. 1999). Even in the US, where the Safe Drinking Water Act regulates this standard, regional studies suggest that $10-20 \%$ of groundwater sources may exceed $10 \mathrm{ppm}$ (Figure 3). Severe instances of groundwater contamination are often associated with livestock production in CAFOs, particularly swine and poultry (Mallin 2000). Groundwater contamination by nitrate may be a particularly serious problem due to its poor reversibility (van Lanen and Dijksma 1999).

The potential health effects of high nitrate levels are diverse, including reproductive problems (Kramer et al. 1996), methemoglobinemia, and cancer. Infants are especially at risk for methemoglobinemia ("blue-baby" syndrome), and while little conclusive evidence exists for this 


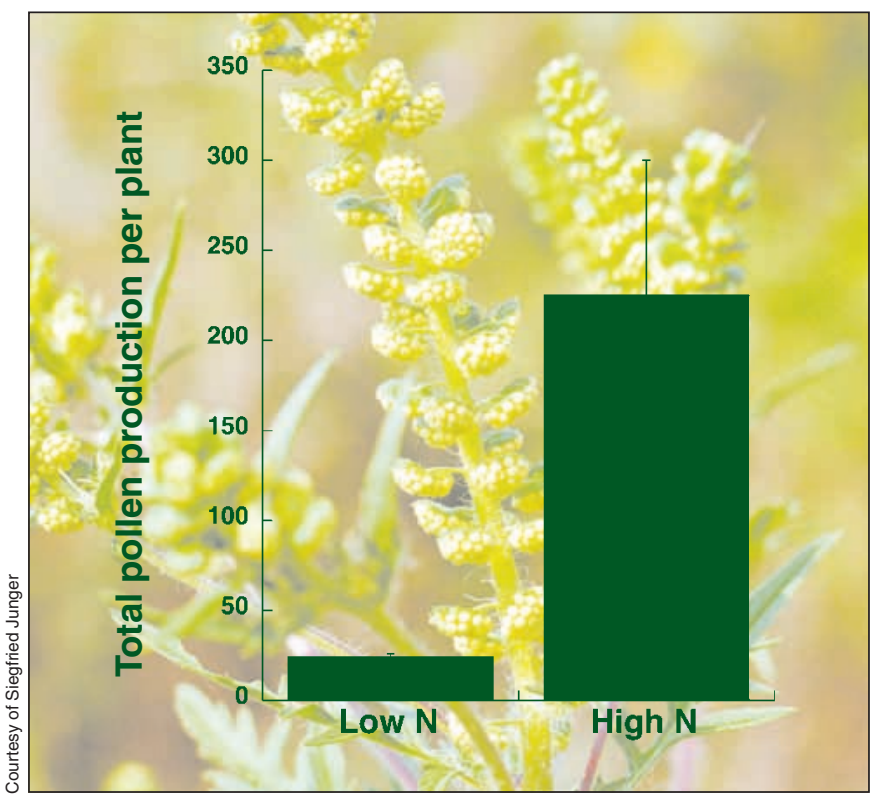

Figure 2. The effects of $N$ additions on pollen production of ragweed (Ambrosia artemisifolia) plants raised in controlled environment greenhouses. Fertilizer amounts were 5 (low) and 15 (high) $\mathrm{gN} / \mathrm{m}^{2} / \mathrm{yr}$, using weekly applications of a time-release fertilizer solution. Error bars are 1 standard deviation. (P Wayne et al. unpublished).

disorder occurring where levels are below 10 ppm, higher values found throughout the world can significantly elevate the risk (Gupta et al. 2000). Some health professionals also believe that methemoglobinemia may often be under- or misdiagnosed (Johnson and Kross 1990).

Recent evidence suggests that nitrate levels even below the WHO standard may stimulate endogenous formation of N-nitrosoamines (van Mannen et al. 1996), compounds strongly implicated in cancer risks. Non-Hodgkin's lymphoma (NHL) has increased dramatically in the US, even discounting AIDS associations, and long-term consumption of water with nitrate- $\mathrm{N}$ concentrations of $6.3 \mathrm{ppm}$ and above has been linked to a higher risk for NHL (Ward et al. 1996). In Iowa, rising nitrate levels well below the $10 \mathrm{ppm}$ standard were associated with an increased risk of bladder and ovarian cancers (Weyer et al. 2001).

\section{Indirect ecological feedbacks to health}

Nitrogen limitation of primary production is widespread in terrestrial and marine ecosystems, as well as in some freshwater ecosystems (Vitousek and Howarth 1991). Human additions of $\mathrm{N}$ to the environment can therefore drive a remarkable range of ecological changes (Vitousek et al. 1997), which almost cer- tainly include the dynamics of some human diseases. For example, many infectious diseases are controlled by vector hosts, and mosquito-borne malaria alone accounts for more than a million deaths every year (WHO 2001). Some evidence now suggests that the abundance and distribution of several important vectors, including the mosquito hosts of malaria and West Nile virus, may be affected by changes in $\mathrm{N}$ availability.

For example, several studies have shown a positive correlation between concentrations of inorganic $\mathrm{N}$ in surface water and larval abundance for malarial Anopheles sp mosquitoes (Rejmankova et al. 1991; Teng et al. 1998), as well as for Culex sp and Aedes sp, carriers of La Crosse encephalitis, Japanese encephalitis, and West Nile virus (Walker et al. 1991; Toth and Melton 2000; Sunish and Reuben 2001). Positive associations between indices of algal productivity and larval abundance have also been found for Anopheles in both Latin America and Africa (Rejmankova et al. 1991, Gimnig et al. 2001). However, not all such associations are positive (Gimnig et al. 2001), and concurrent increases in mosquitoes and eutrophic conditions are probably species, site, and season specific. In general, as with many ecological responses to changing $\mathrm{N}$, the dynamics of a given disease vector are likely to be complex, driven not only by the organism's direct response, but also by those of its food sources, and of the parasitic (Comiskey et al. 1999) and predatory species that affect its abundance.

One clear and widespread effect of an accelerated $\mathrm{N}$ cycle is the eutrophication of coastal and marine eco-systems (NRC 2000), an ecological change which may also affect human health. For example, the worldwide increase in harmful algal blooms (HABs) has been linked to anthropogenic nutrient loading (Burkholder 1998; NRC 2000). HABs can include neurological, amnesic, paralytic, and/or diarrheic shellfish poisoning,

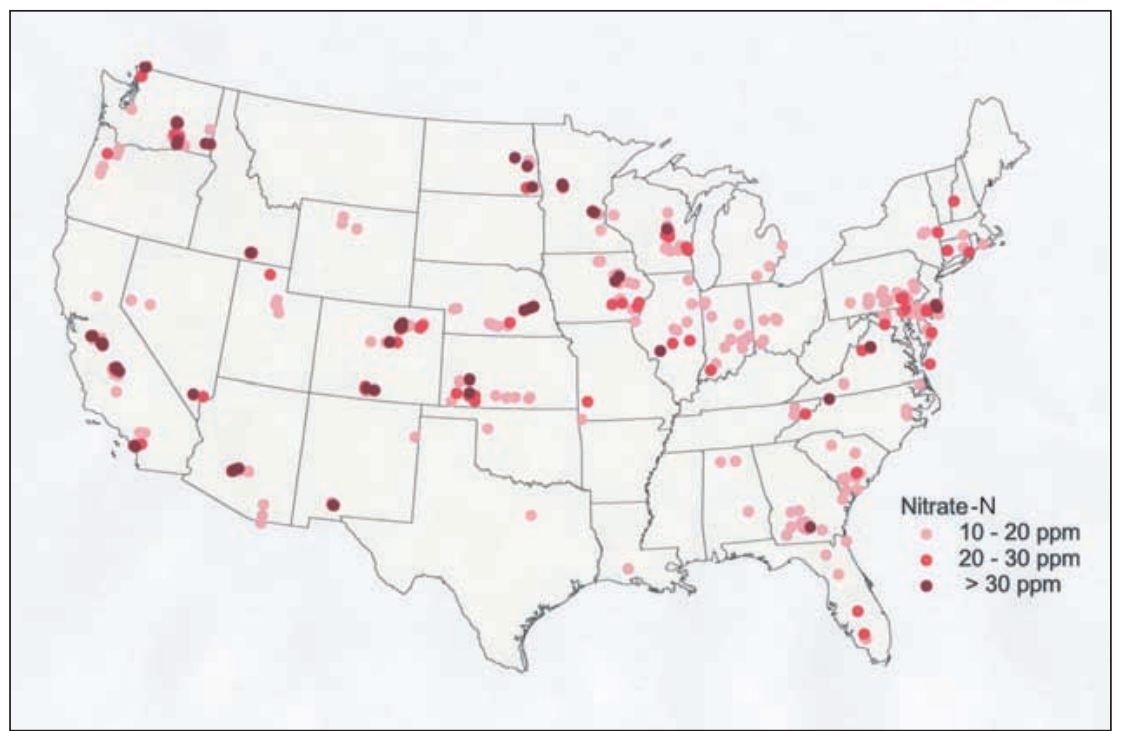

Figure 3. US groundwater nitrate concentrations at or above 10 ppm nitrate-N from the United States Geological Survey NAWQA database (http://orxddwimdn.er.usgs.gov). 
as well as toxins produced by various cyanobacteria, and by the estuarine dinoflagellates Pfiesteria piscicida and $P$ shumwayii (Burkholder 1998). HABs can also indirectly affect humans by disrupting ecosystems and sources of nutrition (NRC 2000). Increased N can also increase the availability of other key nutrients, changes that can, in turn, facilitate blooms of many species of harmful algae (NRC 2000).

Finally, the bacterium Vibrio cholerae is associated with a wide range of marine life, and cholera outbreaks have long been associated with coastal algal blooms (Colwell and Huq 2001; Cottingham et al. 2003). Some evidence suggests that rapid growth of $V$ cholerae can accompany that of marine algae in eutrophic conditions, and high nutrient conditions favoring algal growth have been implicated in recent cholera outbreaks (Epstein 1993; Colwell and Huq 2001).

The study of links between ecological changes due to environmental $\mathrm{N}$ enrichment and the dynamics of human diseases is a relatively new field, yet the results listed above suggest a range of direct and indirect relationships. The combination of theory with recent data on general ecosystem responses can help frame some testable hypotheses. For example, evidence suggests that increasing $\mathrm{N}$ availability often causes overall declines in species diversity (Tilman 1987; Aerts and Berendse 1988). We are aware of no studies demonstrating that lowered diversity due to increasing $\mathrm{N}$ causes a subsequent change in disease dynamics, but theoretical results suggest that reductions in diversity from other drivers can increase the transmission of vector-borne diseases (Ostfeld and Keesing 2000).

In general, we hypothesize that increasing nutrient availability may often favor opportunistic, disease-causing organisms. More broadly, as shown by the examples above, increases in $\mathrm{N}$ availability can clearly lead to a cascade of ecological responses at multiple levels. Such responses, in turn, are likely to cause varied and complex changes in the epidemiology of human diseases that depend on the life histories of disease-causing organisms and their vectors, the structure and composition of food webs controlling their abundance, and the overall sensitivity to $\mathrm{N}$ shown by the ecosystems in which they reside.

\section{Conclusions}

Many health implications of a changing global $\mathrm{N}$ cycle, especially those arising via complex ecological feedbacks, require substantial additional research. Nonetheless, it is clear that current patterns in human $\mathrm{N}_{2}$ fixation and use have consequences for human health well beyond the widely recognized benefits of increasing food production. Moreover, the greatest net benefits are found at low to moderate levels of $\mathrm{N}$ use, and continued environmental $\mathrm{N}$ enrichment will greatly amplify the health costs (Figure 1). Anthropogenic $\mathrm{N}_{2}$ fixation continues to increase exponentially (Galloway and Cowling 2002), and if left unchecked,

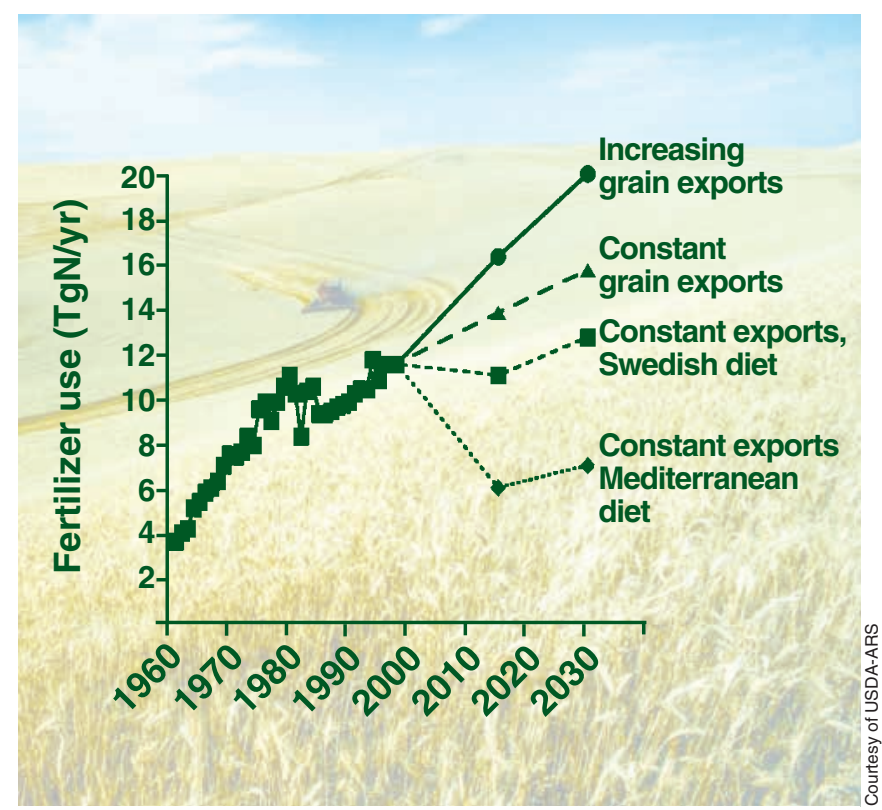

Figure 4. Use of inorganic $N$ fertilizer in the US from 1961-1999 and projections on future use through 2030 based on a "businessas-usual" scenario of increasing grain exports (circles), constant grain exports (triangles), and two alternative diet scenarios with constant grain exports: Swedish diet (squares), and Mediterranean diet (diamonds). Reprinted from Howarth et al. (2002).

both well-understood health risks such as air pollution, as well as potential problems arising from the ecology of disease, are also likely to increase sharply in the coming decades.

Finally, we wish to stress that while changes in the $\mathrm{N}$ cycle and their effects are alarmingly rapid, considerable reductions in $\mathrm{N}$ fixation and use are possible without substantial social or economic costs (Matson et al. 1998; Melillo and Cowling 2002; Moomaw 2002; Oenema and Pietrzak 2002). One simple example is detailed by Howarth et al. (2002), who show that if the average American were to switch to a diet more typical of some European regions, future US fertilizer use could decline substantially (Figure 4). The prospect of switching to the "Mediterranean diet" is particularly intriguing, not only because it would greatly lower $\mathrm{N}$ pollution, as a result of lowered meat consumption, but also because this diet is healthier than today's average American diet (Curtis and O'Keefe 2002). Thus, the potential clearly exists for maximizing the health benefits of some human alteration to the $\mathrm{N}$ cycle, while also greatly reducing both the environmental and health costs.

\section{Acknowledgments}

We thank the National Center for Ecological Analysis and Synthesis (NCEAS) and the Andrew W Mellon Foundation for support of this project, and E Boyer for assistance with the US groundwater data. We also thank Dr Siegfried Junger and the USDA-ARS for permission to use the photos in Figures 2 and 4, respectively. 


\section{References}

Aber JD, Nadelhoffer KJ, Steudler P, and Melillo JM. 1989. Nitrogen saturation in northern forest ecosystems. Bioscience 39: 378-86.

Aerts R and Berendse F. 1988. The effect of increased nutrient availability on vegetation dynamics in wet heathlands. Vegetatio 76: 63-69.

Agrawal GD, Lunkad SK, and Malkhed T. 1999. Diffuse agricultural nitrate pollution of groundwaters in India. Water Sci Technol 39: 67-75.

Ågren GI and Bosatta E. 1988. Nitrogen saturation of terrestrial ecosystems. Environ Pollut 54: 185-97.

Beisel WR. 1982. Synergism and antagonism of parasitic diseases and malnutrition. Rev Infect Dis 4: 746-50.

Beasley R, Keil U, Von Mutius E, et al. 1998. Worldwide variation in prevalence of symptoms of asthma, allergenic rhinoconjunctivitis and atopic eczema: ISAAC. Lancet 351: 1225-32.

Berry N. 1992. Proceedings on global change and the human prospect: issues in population, science, technology and equity. Research Triangle Park, NC: Sigma Xi.

Burkholder JM. 1998. Implications of harmful microalgae and heterotrophic dinoflagellates in management of sustainable marine fisheries. Ecol Appl 8: S37-S62.

Chameides WL, Kasibhatla PS, Yienger J, and Levy H. 1994. Growth of continental scale metro-agro-plexes, regional ozone pollution, and world food production. Science 264: 74-77.

Colwell R and Huq A. 2001. Marine ecosystems and cholera. Hydrobiologia 460: 141-45.

Comiskey NM, Lowrey RC, and Wesson DM. 1999. Role of habitat components on the dynamics of Aedes albopictus from New Orleans. J Med Entomol 36: 313-20.

Cordain L, Watkins BA, Florant GL, et al. 2002. Fatty acid analysis of wild ruminant tissues: evolutionary implications for reducing diet-related chronic disease. Eur J Clin Nutr 56: 181-91.

Cottingham KL, Chiavelli DA, and Taylor RA. 2003. Environmental microbe and human pathogen: the ecology and microbiology of Vibrio cholerae. Front Ecol Environ 2: 80-86.

Curtis BM and O'Keefe JH. 2002. Understanding the Mediterranean diet - could this be the new "gold standard" for heart disease prevention? Postgrad Med 112: 35-44.

Epstein P. 1993. Algal blooms in the spread and persistence of cholera. BioSystems 31: 209-21.

Galloway JN, Schlesinger WH, Levy H, et al. 1995. Nitrogen fixation: atmospheric enhancement - environmental response. Global Biogeochem Cy 9: 235-52.

Galloway JN and Cowling EB. 2002. Reactive nitrogen and the world: 200 years of change. Ambio 31: 64-71.

Gimnig JE, Ombok M, Kamau L, and Hawley WA. 2001. Characteristics of larval anopheline (Diptera: Culicidae) habitats in western Kenya. J Med Entomol 38: 282-88.

Gupta SK, Gupta RC, Seth AK, et al. 2000. Methaemoglobinaemia in areas with high nitrate concentration in drinking water. Natl Med J India 13: 58-61.

Howarth RW, Boyer EW, Pabich WJ, and Galloway JN. 2002. Nitrogen use in the United States from 1961-2000 and potential future trends. Ambio 31: 88-96.

Hu FB and Willett WC. 2002. Optimal diets for prevention of coronary heart disease. JAMA 288: 2569-78.

Johnson CJ and Kross BC. 1990. Continuing importance of nitrate contamination of groundwater and wells in rural areas. Am J Ind Med 18: 449-56.

Kramer MH, Herwaldt BL, Craun GF, et al. 1996. Surveillance of waterborne-disease outbreaks - United States, 1993-1994. CDCP Surveillance Summaries, MMWR 45: 1-33.

Lau TC, Lu X, Coide RT, and Stepenson AG. 1995. Effects of soil fertility and mycorrhizal infection on pollen production and pollen grain size of Cucurbita-Pepo (Cucurbitaceae). Plant Cell Environ 18: 169-77.
Mallin MA. 2000. Impacts of industrial animal production on rivers and estuaries. Am Sci 88: 2-13.

Malm WC, Pitchford ML, Scruggs M, et al. 2000. Spatial and seasonal patterns and temporal variability of haze and its constituents in the United States. Fort Collins, CO: Cooperative Institute for Research in Atmosphere.

Matson PA, Parton WJ, Power AG, and Swift MJ. 1997. Agricultural intensification and ecosystem properties. Science 277: 504-08.

Matson PA, Naylor R, and Ortiz-Monasterio I. 1998. Integration of environmental, agronomic, and economic aspects of fertilizer management. Science 280: 112-15.

McConnell R, Berhane K, Gilliland F, et al. 2002. Asthma in exercising children exposed to ozone: a cohort study. Lancet 359 : 386-91.

Melillo JM and Cowling EB. 2002. Reactive nitrogen and public policies for environmental protection. Ambio 31: 150-58.

Moomaw WR. 2002. Energy, industry and nitrogen: strategies for decreasing reactive nitrogen emissions. Ambio 31: 184-89.

National Institutes of Health (NIH). 1993. Something in the air: airborne allergens. Bethesda, MD: NIH.

National Research Council (NRC). 2000. Clean coastal waters. Washington, DC: National Academy Press.

Nesheim MC. 1993. Human nutrition needs and parasitic infections. Parasitology 107: S7-S18.

Oenema O, Boers PCM, van Eerdt MM, et al. 1998. Leaching of nitrate from agriculture to groundwater: the effect of policies and measures in the Netherlands. Environ Pollut 102: 471-78.

Oenema $\mathrm{O}$ and Pietrzak S. 2002. Nutrient management in food production: achieving agronomic and environmental targets. Ambio 31: 159-68.

Ostfeld RS and Keesing F. 2000. Biodiversity and disease risk: the case of Lyme disease. Conserv Biol 14: 722-28.

Pope CA, Burnett RT, Thun MJ, et al. 2002. Lung cancer, cardiopulmonary mortality, and long-term exposure to fine particulate air pollution. J Am Med Assoc 287: 1132-41.

Rejmankova E, Savage HM, Rejmanek M, et al. 1991. Multivariate analysis of relationships between habitats, environmental factors and occurrence of Anopheline mosquito larvae Anopheles albimanus and A pseuodopunctipennis in southern Chiapas, Mexico. J Appl Ecol 28: 827-41.

Sanchez PA. 2002. Soil fertility and hunger in Africa. Science 295: 219-20.

Smil VA. 2000. Feeding the world: a challenge for the twenty-first century. Cambridge, MA: MIT Press.

Spannhake EW, Reddy SPM, Jacoby DB. et al. 2002. Synergism between rhinovirus infection and oxidant pollutant exposure enhances airway epithelial cell cytokine production. Environ Health Persp 110: 665-70.

Teng HJ, Wu YL, Wang SJ, and Lin C. 1998. Effects of environmental factors on abundance of Anopheles minimus larvae and their seasonal fluctuations in Taiwan. Environ Entomol 27: 324-28.

Tilman D. 1987. Secondary succession and the pattern of plant dominance along experimental nitrogen gradients. Ecol Monogr 57: 189-214.

Toth SJ and Melton TA. 2000. North Carolina Pest News, NC Coop Ext Serv, 16.

van Dam RM, Stampfer M, Willett WC, et al. 2002. Dietary fat and meat intake in relation to risk of type 2 diabetes in men. Diabetes Care 25: 417-24.

van Lanen HAJ and Dijksma R. 1999. Water flow and nitrate transport to a groundwater-fed stream in the Belgian-Dutch chalk region. Hydrol Process 13: 295-307.

van Maanen JMS, Welle IJ, Hageman G, et al. 1996. Nitrate contamination of drinking water: relationship with HPRT variant frequency in lymphocyte DNA and urinary excretion of Nnitrosamines. Environ Health Persp 104: 522-28. 
Vitousek PM, Aber J, Howarth RW, et al. 1997. Human alteration of the global nitrogen cycle: causes and consequences. Ecol Appl 7: 737-50.

Vitousek PM and Howarth RW. 1991. Nitrogen limitation on land and sea: how can it occur? Biogeochemistry 13: 87-115.

von Mutius E. 2000. Current review of allergy and immunology. J Allergy Clin Immun 105: 9-19.

Walker ED, Lawson DL, Merritt RW, et al. 1991. Nutrient dynamics, bacterial populations and mosquito productivity in treehole ecosystems and microcosms. Ecology 72: 1529-46.

Ward MH, Mark SD, Cantor KP, et al. 1996. Drinking water nitrate and the risk of Non-Hodgkin's Lymphoma. Epidemiology 7 465-71.

Wayne P, Foster S, Connolly J, et al. 2002. Production of allergenic pollen by ragweed (Ambrosia artemisiifolia $\mathrm{L}$ ) is increased in $\mathrm{CO}_{2}$-enriched atmospheres. Ann Allerg Asthma Im 8: 279-88.

Weisburger JH. 2002. Lifestyle, health and disease prevention: the underlying mechanisms. Eur J Cancer Prev 11: S1-S7.

Weyer PJ, Cerhan J, Kross BC, et al. 2001. Municipal drinking water nitrate level and cancer risk in older women: the Iowa Women's Health Study. Epidemiology 12: 327-38.

Wolfe AH and Patz JA. 2002. Reactive nitrogen and human health: acute and long-term implications. Ambio 31: 120-25.
World Health Organization (WHO). 2001. World health report. Geneva, Switzerland: WHO.

Zimmet P, Alberti KGMM, and Shaw J. 2001. Global and societal implications of the diabetes epidemic. Nature 414: 782-87.

(Author addresses continued) ${ }^{4}$ The Ecosystems Center, Woods Hole Marine Biological Laboratory, Woods Hole, MA; ${ }^{5}$ Institute of Arctic and Alpine Research, University of Colorado, Boulder, CO; ${ }^{6}$ Dept of Ecology and Evolutionary Biology and Program in Environmental Studies, University of Colorado, Boulder, CO; ${ }^{7}$ Department of Ecology and Evolutionary Biology, Princeton University, Princeton, NJ; ${ }^{8}$ Department of Environmental Health, Harvard School of Public Health, Boston, MA, Boston, MA; ${ }^{9}$ Atmospheric Chemistry Division, National Center for Atmospheric Research, Boulder, CO; ${ }^{10}$ Institute for Agriculture and Trade Policy, Minneapolis, MN; ${ }^{11}$ Center for Marine Science, University of North Carolina at Wilmington, Wilmington, NC; ${ }^{12}$ Department of Environmental Health, Harvard School of Public Health, Boston, MA; ${ }^{13}$ New England School of Acupuncture, Watertown, MA; ${ }^{14}$ Visteon Corporation, Sterling Heights, MI 